\title{
PENGEMBANGAN BUKU SAKU UNTUK MENINGKATKAN PEMAHAMAN SISWA DALAM MATA PELAJARAN PAI MATERI TATA CARA SALAT KELAS II SD
}

\author{
Avivatul Novi Aziza, Suyatno \\ Universitas Ahmad Dahlan \\ avivatulnoviaziza@gmail.com
}

\begin{abstract}
ABSTRACK
This study aims to: 1) determine the feasibility developing pocket book teaching materials on PAI subjects in class II elementary school prayer materials. 2) knowing the feasibility of PAI pocket book teaching materials for the procedure for prayer in class II of elementary school. 3) knowing the results of product trials in students' understanding through PAI pocket book teaching materials on the procedures for the elementary school class II prayer. This research is a study Research and Development (R \& D). The steps are carried out, namely: (1) analysis of potential and problems, (2) data collection, (3) product design, (4) design validation, (5) design revisions, (6) product testing, and (7) product revisions, (8) usage trials. The data analysis technique used is the analysis of quantitative and qualitative data. The results of the study show that 1) the steps to develop a pocket book teaching material product include: 2) the feasibility of pocket books is done through the assessment of learning experts, material experts, linguists, and media experts. The assessment of the feasibility results from the learning expert gets a score of 75 (Good), the assessment of the material gets a score of 90 (Very good), the assessment of the linguist gets a score of 82.5 (Very Good), and the media expert gets a score of 100 (Very Good) It can be concluded that this pocket book is suitable for use. Based on product trials, it can be concluded that the pocket book material for prayer can improve student understanding as evidenced by the results of Pre Test the small group61 (Good) increasing to a value of 83 (Very Good) can be seen from the results of the Post Test. The trial of a large group of products was concluded that the book pocket material for prayer can improve students' understanding by proving that the Pre Test results scored 63.6 (Good) increased to 95 (Very Good) seen from the results of the Post Test.
\end{abstract} Keywords: pocketbook, islamic education, understanding, elementary school students

\begin{abstract}
ABSTRAK
Penelitian ini bertujuan untuk 1) mengetahui langkah-langkah pengembangan bahan ajar buku saku pada mata pelajaran PAI materi tata cara salat kelas II Sekolah Dasar. 2) mengetahui kelayakan bahan ajar buku saku PAI materi tata cara salat pada kelas II Sekolah Dasar. Penelitian ini merupakan penelitian Research and Development (R\&D). Tahap-tahap yang dilakukan yaitu: (1) analisis potensi dan masalah, (2) pengumpulan data, (3) desain produk, (4) validasi desain, (5) revisi desain, (6) uji coba produk, dan (7) revisi produk, (8) uji coba pemakaian. Teknik analisis data yang digunakan yaitu analisis data kuantitatif dan kualitatif. Hasil penelitian menunjukkan bahwa 1) langkah-langkah pengembangan produk bahan ajar buku saku. 2) kelayakan
\end{abstract}


buku saku dilakukan melalui penilaian para ahli pembelajaran, ahli materi, ahli bahasa, dan ahli media. Penilaian hasil kelayakan dari ahli pembelajaran mendapat nilai 75 (Baik), penilaian materi mendapat nilai 90 (Sangat baik), penilaian ahli bahasa mendapat nilai 82,5 (Sangat Baik), dan ahli media mendapat nilai 100 (Sangat Baik) dari hasil penilaian tersebut dapat disimpulkan bahwa buku saku ini layak digunakan. 3) Berdasarkan uji coba produk dapat disimpulkan bahwa buku saku materi tata cara salat dapat meningkatkan pemahaman siswa dibuktikan dengan hasil Pre Test kelompok kecil 61 (Baik) meningkat menjadi nilai 83 (Sangat Baik) dapat dilihat dari hasil Post Test. Uji coba produk kelompok besar disimpulkan bahwa buku saku materi tata cara salat dapat meningkatkan pemahaman siswa dengan dibuktikan hasil Pre Test mendapat nilai 63,6 (Baik) meningkat menjadi 95 (Sangat Baik) dilihat dari hasil Post Test.

Kata kunci: Buku Saku, Pendidikan Agama Islam, Pemahaman, Siswa Sekolah Dasar

\section{PENDAHULUAN}

Pembelajaran merupakan segala upaya yang dilakukan oleh guru (pendidik) agar terjadi proses belajar pada diri siswa. Secara implisit, dalam pembelajaran ada kegiatan memilih, menetapkan dan mengembangkan metode untuk mencapai hasil pembelajaran yang diinginkan. Pembelajaran lebih menekankan pada cara-cara untuk mencapai tujuan dan berkaitan dengan bagaimana cara mengorganisasikan materi pelajaran, menyampaikan materi pelajaran, dan mengelola pembelajaran. Oleh karena itu, segala sesuatu yang mendukung keberhasilan dalam pembelajaran perlu diperhatikan agar dapat menciptakan suasana pembelajaran yang kondusif, agar siswa benar-benar tertarik dan ikut aktif dalam proses pembelajaran. Kaitannya dengan usaha untuk menciptakan suasana pembelajaran yang kondusif, media merupakan salah satu faktor yang turut menentukan keberhasilan pembelajaran. Media merupakan alat yang digunakan untuk menyalurkan pesan atau informasi dari pengirim kepada penerima pesan. Dalam aktivitas pembelajaran, media didefinisikan sebagai sesuatu yang dapat membawa informasi dan pengetahuan dalam interaksi yang berlangsung antara guru dengan siswa. Selain media, guru juga perlu untuk mengembangkan bahan ajar dalam mencapai hasil dan tujuan suatu pembelajaran. Menurut Majid (2005) bahan ajar merupakan segala bentuk bahan pembelajaran yang dapat digunakan oleh peserta didik untuk membantu dalam melaksanakan kegiatan belajar mengajar. Salah satu bahan ajar yang dapat digunakan untuk membantu proses pembelajaran adalah bahan ajar cetak (printed). Menurut Wahyuningsih (2013) bahan ajar cetak adalah sejumlah bahan yang disiapkan dalam kertas yang dapat berfungsi untuk keperluan pembelajaran atau penyampaian informasi.

Pembelajaran Pendidikan Agama Islam (PAI) berkaitan dengan media yang dipilih semestinya mempertimbangkan karakteristik materi pembelajaran PAI itu sendiri dan juga kompetensi yang ingin dikembangkan. Mata pelajaran PAI adalah mata pelajaran yang mengajarkan tentang tuntunan hidup yang sesuai dengan nilai-nilai ajaran agama. Sebagai tuntuan hidup, muatan pembelajaran PAI sangat kompleks karena mencangkup seluruh dimensi kehidupan manusia. Secara garis besarnya, pokok-pokok materi PAI terdiri atas materi aqidah yang mengajarkan tentang kosep ideologi Islam, akhlak sebagai tuntunan perilaku umat Islam, ibadah mengajarkan tentang cara mendekatkan diri pada Allah, tarikh atau sejarah Islam serta pokok-pokok materi lainnya yang berkaitan dengan kehidupan umat Islam. Dengan memahami materi PAI tersebut, maka media yang dipilih semestinya mempertimbangkan karakteristik setiap materi yang hendak diajarkan.

Selama ini pembelajaran PAI hanya didominasi dengan ceramah saja, dimana guru 
berdiri didepan kelas menjelaskan materi pelajaran sedang siswa secara pasif mendengarkan penjelasan guru. Cara mengajar demikian itu tentu sudah tidak relevan karena mengabaikan subtansi belajar itu sendiri. Pembelajaran yang menempatkan siswa sebagai objek yang pasif cenderung membuat siswa jenuh dalam belajar. Berdasarkan wawancara di SD Muhammadiyah Trisigan pada bulan November 2017 ditemukan beberapa masalah yang muncul dalam pembelajaran PAI saat sedang berlangsung seperti guru belum menggembangkan bahan ajar yang menarik, guru masih terbatas pada buku paket, kegiatan pembelajaran yang dilakukan oleh guru terlalu sering menggunakan metode ceramah dan dalam kegiatan praktik salat dilakukan secara klasikal sehingga siswa cenderung kurang tertarik sehingga masih ditemukan siswa yang belum bisa menghafal bacaan shalat sesuai dengan gerakan. Pertama, guru belum menggunakan bahan ajar yang menarik, hal ini terlihat saat pembelajaran guru hanya menggunakan buku paket dari sekolah saja. Guru tidak menggunakan bahan ajar yang lain. Observasi yang dilakukan pada mata pelajaran PAI materi tata cara salat. Buku paket yangdigunakan hanya berisi rangkuman materi, kurangnya gambar yang mendukung materi, gambar yang tidak berwarna, dan ukuran buku paket yang besar sehingga sulit untuk di bawa kemana-mana. Kedua, siswa merasa kurang tertarik dengan pembelajaran. Hal ini di dapat dari hasil wawancara dengan beberapa siswa di kelas II SD Muhammadiyah Trisigan. Siswa mengatakan bahwa kurang tertarik dengan pembelajaran sehingga membuat siswa merasa bosan dalam mengikuti pembelajaran. Hal ini mengakibatkan siswa kurang memahami materi yang diajarkan oleh guru khususnya materi tata cara salat.

Bahan ajar yang dapat digunakan untuk membantu proses pembelajaran adalah bahan ajar cetak. Menurut Prastowo (2011) bahan ajar cetak adalah sejumlah bahan yang disiapkan dalam kertas yang dapat berfungsi untuk keperluan pembelajaran atau penyampaian informasi. Bahan ajar cetak salah satunya yaitu buku saku. Buku saku merupakan suatu buku yang berukuran kecil yang mana berisi informasi yang dapat disimpan di saku sehingga mudah dibawa kemana-mana. Peneliti memilih menggunakan bahan ajar buku saku ini karena lebih praktis dalam penggunaanya, serta praktis dalam penggunaanya saat ingin belajar di mana pun dan kapan pun dan lebih menarik dengan materi yang lengkap dan gambar yang berwarna. Pengembangan bahan ajar buku saku ini didasarkan pada prinsip menyesuaikan dengan kemampuan siswa dan kondisi yang ada di sekolah dengan tetap fokus pada pencapaian tujuan pembelajaran pengembangan bahan ajar buku dalam penelitian ini menggunakan subjek kelas II. Dengan buku saku ini diharapkan siswa lebih tertarik pada penyampaian materi tata cara salat serta mampu menghafalkan gerakan shalat dengan benar.

\section{METODE PENELITIAN}

Jenis penelitian yang digunakan dalam penelitian ini adalah Research and Development (R\&D) dari Sugiyono (2013) dengan pembatasan hanya sampai ke tahap 8 yaitu: analisis potensi dan masalah, pengumpulan data, desain produk, validasi produk, revisi desain, uji coba produk, uji coba produk, dan revisi produk dan uji coba produk pemakaian. Jenis data yang digunakan dalam penelitian pengembangan bahan ajar buku saku yakni data kualitatif dan kuantitatif mengenai proses pengembangan produk serta tingkat kelayakan atau keualitas produk sesuai prosedur pengembangan yang ditentukan. Adapun data tersebut dari hasil kritik, saran, dan komentar dari para ahli (ahli pembelajaran, ahli materi, ahli bahasa, dan ahli media) dan guru saat dilakukan uji validasi dan uji coba produk. Hasil angket respon siswa terhadap penggunaan bahan ajar buku saku. Data kualitatif berupa kriteria penilaian yaitu Sangat Baik, Baik, Kurang Baik, Tidak Baik. Data kuantitatif dari pengembangan bahan ajar buku saku dilakukan oleh para ahli (ahli 
pembelajaran, ahli materi, ahli bahasa, ahli media) saat melakukan validasi serta guru dan siswa saat melakukan uji coba produk, dan hasil Pre Test dan Post Test.

Teknik Analisis Data, data penelitian pengembangan bahan ajar buku saku menggunakan teknik analisis data secara kualitatif dan kuantitatif. Data kualitatif diperoleh dari komentar dan saran dari hasil validasi ahli, lembar pengamatan guru dan lembar respon siswa. Sedangkan data kuantitatif diperoleh dari skor hasil validasi para ahli pembelajaran, materi, bahasa, media, guru, respon siswa dalam uji coba produk, dan hasil Pre Test dan hasil Post Test. Skala penelitian yang digunakan dalam isian alternatif bergradasi 4 (Suharsimis,2009) sebagai berikut:

Tabel 1. Skala Penilaian

\begin{tabular}{lcl}
\hline Jawaban yang dipilih & Bobot penilaian & Kategori \\
\hline Sangat Setuju & 4 & Sangat baik \\
\hline Setuju & 3 & Baik \\
\hline Kurang Setuju & 2 & Kurang baik \\
\hline Tidak Setuju & 1 & Tidak baik \\
\hline
\end{tabular}

Pada penelitian ini skala penilaian secara lebih rinci yang digunakan adalah sebagai berikut: Kategori sanga baik (SB) meliputi: sangat mudah dipahami, sangat jelas, sangat menarik, sangat sesuai, sangat bermanfaat diberi nilai 4. Kategori baik (B) meliputi: mudah dipahami, jelas, menarik, sesuai, dan bermanfaat diberi nilai 3. Kategori kurang baik (KB) meliputi: kurang mudah dipahami, kurang jelas, kurang menarik, kurang sesuai, dan kurang bermanfaat diberi nilai 2. Kategori tidak baik (TB) meliputi: tidak mudah dipahami, tidak jelas, tidak menarik, tidak sesuai, dan tidak bermanfaat diberi nilai 1 .

$$
\text { nilai: } \frac{\text { jumlah skor yang diperoleh }}{\text { jumlah skor maksimum }} \times 100
$$

Apabila telah diperoleh nilai, maka untuk mengetahui kelayakan bahan ajar buku saku selanjutnya ditafsirkan penilaian tersebut ke dalam kategori : sangat baik, cukup baik, kurang baik, sangat kurang baik sesuai dengan Suharsimi \& Cepi (2009: 35) sebagai berikut.

$\begin{array}{ll}\text { Skor } 81-100 & =\text { Sangat baik } \\ \text { Skor } 61-80 & =\text { Baik } \\ \text { Skor } 41-60 & =\text { Cukup } \\ \text { Skor } 21-40 & =\text { Kurang baik } \\ \text { Skor }<21 & =\text { Sangat kurang baik }\end{array}$

Berdasarkan perhitungan yang diperoleh skor dan rata-rata, pengembangan bahan ajar buku saku dikatakan layak digunakan sebagai bahan ajar pembelajaran PAI materi tata cara salat SD Muhammadiyah Trisigan apabila memiliki nilai baik.

\section{HASIL DAN PEMBAHASAN}

Data uji coba ini berupa data kualitatif dan data kuantitatif. Data kualitatif diperoleh berdasarkan masukan, pendapat, komentar dan saran dari ahli pembelajaran, ahli materi, ahli bahasa, ahli media. Selain itu, dari respon guru dan respon siswa yang dinyatakan dalam bentuk kata- kata atau penyataan. Sedangkan data kuantitatif diperoleh dari penilaian respon guru dan siswa dalam uji coba produk, dan hasil Pre Test dan Post Test yang dinyatakan dalam bentuk angka atau skor yang kemudian dihitung menggunakan rumus yang ditentukan.

Validasi ahli pembelajaran tehadap bahan ajar buku saku yang dilakukan oleh Ibu Fitri Indiraini, M.Pd.I dosen PGSD FKIP UAD yang berkompeten dibidangnya. Penilaian terhadap kesesuaian proses pembelajaran yang dilakukan melalui RPP yang telah dibuat. 
Hasil penilaian memperoleh nilai 75 dan termasuk dalam kategori Baik (B). Validasi ahli materi terhadap bahan ajar buku saku yang dilakukan oleh Ibu Nurul Hidayati Rofiah, M.Pd.I. dosen PGSD FKIP UAD yang berkompeten dibidangnya. Penilaian yang dilakukan meliputi penilaian terhadap KI,KD,Indikator yang disesuaikan. Hasil penilaian memperoleh nilai 90 dan termasuk dalam kategori Sangat Baik (SB). Validasi ahli bahasa terhadap bahan ajar buku saku yang dilakukan oleh Bapak Sugeng Riyanto, M.Pd.. dosen PGSD FKIP UAD yang berkompeten dibidangnya. Penilaian yang dilakukan meliputi penilaian terhadap keefektifan bahasa yang digunakan dalam buku saku. hasil penilaian memperoleh nilai 82,5 dan termasuk dalam kategori Sangat Baik (SB). Validasi ahli materi terhadap bahan ajar buku saku yang dilakukan oleh Bapak Lovandri Dwanda Putra, M.Pd.I. dosen PGSD FKIP UAD yang berkompeten dibidangnya. Penilaian yang dilakukan meliputi kualitas dan kelayakan spesifik produk dari segi bahan ajar. Hasil penilaian memperoleh nilai 100 dan termasuk dalam kategori Sangat Baik (SB).

Data hasil uji coba produk dilakukan dengan tujuan mengahui respon guru dan siswa terhadap penilaian bahan ajar buku saku. penilaian siswa berdasarkan jawaban "ya" atau "tidak". Hasil respon siswa kelompok kecil mendapat nilai 93 dan masuk dalam kategori Sangat Baik (SB), dan hasil respon siswa kelompok besar mendapat nilai 98,12 masuk dalam kategori Sangat Baik (SB). Hasil respon guru mendapat nilai 92,85 masuk dalam kategori Sangat Baik (SB). Dan uji coba produk dalam meningkatkan pemahaman siswa bahan melalui bahan ajar buku saku dapat dibuktikan dari hasil Pre Tes dan Post Test dari kelompok kecil dan kelompok besar.

Hasil Pre Test kelompok kecil mendapat nilai 61 dalam kategori Baik (B) meningkat menjadi 83 dari hasil Post Test masuk dalam kategori Sangat Baik (SB). Uji coba produk kelompok besar disimpulkan bahwa buku saku materi tata cara salat dapat meningkatkan pemahaman siswa dengan dibuktikan hasil Pre Test mendapat nilai 63,6 katgeori Baik (B), meningkat menjadi 95 masuk dalam kategori Sangat Baik (SB) dilihat dari hasil Post Test. Dari hasil pre test dan post test tersebut dapat dilihat perbedaan bahwa ada peningkatan pemahaman siswa setelah penggunaan bahan ajar buku saku. nilai siswa yang sebelumnya tanpa penggunaan bahan ajar buku saku terlihat rendah dibandingkan setelah pembelajaran menggunakan bahan ajar buku saku nilai yang diperoleh siswa pun meningkat. Dapat disimpulkan bahwa penggunaan bahan ajar buku saku dapat meningkatkan pemahaman siswa kelas II Sekolah Dasar Muhammadiyah Trisigan.

Tabel 1. Keseluruham dari Penilaian.

\begin{tabular}{llll}
\hline No & Penilaian & Nilai & Kategori \\
\hline 1 & Ahli pembelajaran & 75 & Baik \\
\hline 2 & Ahli materi & 90 & Sangat Baik \\
\hline 3 & Ahli Bahasa & 82,5 & Sangat Baik \\
\hline 4 & Ahli media & 100 & Sangat Baik \\
\hline 5 & Penilaian Guru & 92,85 & Sangat Baik \\
\hline 6 & Uji coba kelompok kecil & 93 & Sangat Baik \\
\hline 7 & Uji coba kelompok besar & 98,12 & Sangat Baik \\
\hline 8 & Hasil Pre Test kelompok kecil & 61 & Baik \\
\hline 9 & Hasil Pre Test kelompok besar & 63,6 & Baik \\
\hline 10 & Hasil Post Test kelompok kecil & 83 & Sangat Baik \\
\hline 11 & Hasil Post Test kelompok besar & 95 & Sangat Baik \\
\hline Jumlah Skor & \multicolumn{2}{c}{$\mathbf{9 3 4 , 0 7}$} \\
\hline$\quad$ kategori & \multicolumn{2}{c}{ Sangat Baik } \\
\hline
\end{tabular}


Revisi produk dilakukan berdasarkan saran maupun komentar dari ahli pembelajaran, ahli materi, ahli bahasa, ahli media. 1) hasil ahli pembelajaran yakni perbaikan pada kegiatan pembelajaran di RPP. 2) hasil uji validasi ahli materi mendapat revisi pada KI, KD, Indikator yang harus sesuai. 3) hasil uji validasi ahli bahasa mendapat revisi pada keefektifan kalimat yang terdapat di buku saku. 4) hasil uji validasi ahli media mendapat revisi pada cover depan penambahan logo UAD dan nama PGSD, penambahan tokoh kartun yang terdapat dibuku saku.

Hasil penilaia yang diperoleh dari masing-masing penilai dapat dijelaskan sebagai berikut: 1) data yang diperoleh dari tahap validasi ahli pembelajaran mendapat nilai 75 masuk ke dalam kategori Baik. 2) Data yang diperoleh oleh validasi materi mendapat nilai 90 masuk kedalam kategori Sangat Baik. 3) Data yang diperoleh dari validasi ahli bahasa mendapat nilai 82.5 masuk dalam kategori Sangat Baik. 4) Data yang diperoleh dari validasi ahli media mendapat nilai 100 masuk dalam kategori Sangat Baik. 5) Data yang diperoleh dari respon guru mendapat nilai 92,85 masuk dalam kategori Sangat Baik, 6) Data yang diperoleh dari uji coba produk kelompok kecil mendapat nilai 93 masuk dalam kategori Sangat Baik. 7) Data yang diperoleh dari uji coba produk kelompok besar mendapat nilai 98,12 masuk dalam kategori Sangat Baik. 8) hasil Pre Test kelompok kecil mendapat nilai 61 masuk dalam kategori Baik meningkat dalam hasil Post Test mendapat nilai 83 masuk dalam kategori Sangat Baik. 9) hasil Pre Test kelompok besar mendapat nilai 63,6 masuk kategori Baik, meningkat dalam hasil Post Test mendapat nilai 95 masuk dalam kategori Sangat Baik.

\section{SIMPULAN}

Penelitian dan pengembangan yang dilakukan sesuai dengan langkah- langkah model penelitian pengembangan oleh sugiyono yang terdiri dari 7 tahap yaitu potensi dan masalah, pengumpulan data, desain produk, validasi produk, revisi produk, uji coba produk, dan revisi produk akhir. Dalam pengembangan bahan ajar buku saku melalui langkah- langkah sebagai berikut: a) Analisis potensi dan masalah: Tahap analisis potensi dan masalah melakukan analisis kebutuhan meliputi wawancara terkait keadaan dilapangan. b) Pengumpulan Data: Pengumpulan yang di dalamnya terdapat KI, KD, Indikator, materi yang dibutuhkan untuk membuat bahan ajar buku saku. c) Desain Produk: Desain produk ini menentukan desain yang akan dibuat yakni berupa materi yang di sketsakan di dalam story board. d) Validasi Desain: Validasi desain dilakukan oleh dosen ahli dari PGSD UAD. Validasi desain di bahan ajar buku saku ini terdiri dari empat ahli desain yakni, ahli pembelajaran, ahli materi, ahli bahasa, dan ahli media. e) Revisi Desain: Bahan ajar buku saku yang sudah divalidasikan oleh empat ahli di revisi sesuai dengan komentar dan saran yang diberikan. f) Uji Coba Produk: Bahan ajar yang sudah direvisi diuji cobakan pada kelompok kecil yang berjumlah 10 siswa kelas II SD. g) Revisi produk akhir: Bahan ajar yang sudah diuji cobakan mendapat masukan dari guru dan siswa. h) Uji coba pemakaian: Uji coba pemakaian dilakukan pada kelompok besar yang berjumlah 11 siswa kelas II SD.

Bahan ajar buku saku yang dikembangkan dalam mata pelajaran Pendidikan Agama Islam materi tata cara salat kelas II SD Muhammadiyah Trisigan dinyatakan layak untuk digunakan sebagai bahan ajar PAI. Hal ini berdasarkan penilaian dari para ahli (ahli pembelajaran, ahli materi, ahli bahasa, dan ahli media), guru dan siswa sebagai berikut. a) Hasil penilaian ahli pembelajaran, pada bahan ajar buku saku diperoleh nilai 75 dengan kategori Baik. b) Hasil penilaian ahli materi, pada bahan ajar buku saku diperoleh nilai 90 dengan kategori Sangat Baik. c) Hasil penilaian ahli bahasa, pada Bahan ajar buku saku yang dikembangkan dalam mata pelajaran Pendidikan Agama Islam materi tata cara 
salat kelas II SD Muhammadiyah Trisigan dinyatakan layak untuk digunakan sebagai bahan ajar PAI. Hal ini berdasarkan penilaian dari para ahli (ahli pembelajaran, ahli materi, ahli bahasa, dan ahli media), guru dan siswa sebagai berikut. a) Hasil penilaian ahli pembelajaran, pada bahan ajar buku saku diperoleh nilai 75 dengan kategori Baik. b) Hasil penilaian ahli materi, pada bahan ajar buku saku diperoleh nilai 90 dengan kategori Sangat Baik. c) Hasil penilaian ahli bahasa, pada bahan ajar buku saku diperoleh nilai 82,5 dengan kategori Sangat Baik. d) Hasil penilaian ahli media, pada bahan ajar buku saku diperoleh nilai 100 dengan kategori Sangat Baik. e) Hasil dari penilaian Guru agama II SD Muhammadiyah Trisigan mendapat nilai 92,8 dengan kategori Sangat Baik.

Berdasarkan uji coba produk dapat disimpulkan bahwa buku saku materi tata cara salat dapat meningkatkan pemahaman siswa dibuktikan dengan hasil Pre Test kelompok kecil 61 (Baik) meningkat menjadi nilai 83 (Sangat Baik) dapat dilihat dari hasil Post Test. Uji coba produk kelompok besar disimpulkan bahwa buku saku materi tata cara salat dapat meningkatkan pemahaman siswa dengan dibuktikan hasil Pre Test mendapat nilai 63,6 (Baik) meningkat menjadi 95 (Sangat Baik) dilihat dari hasil Post Test.

\section{DAFTAR PUSTAKA}

Abdul Madjid dan Dian Andayani. (2004). Pendidikan Agama Islam Berbasis Kompetensi Konsep dan Impelementasi Kurikulum. Bandung: Remaja Rosdakarya.

Prastowo, A. (2013). Panduan Kreatif Membuat Bahan Ajar Inovatif. Yogyakarta: Diva Press

Sugiono. (2013). Metode Penelitian dan Pengembangan Research and Development. Bandung: Alfabeta

Suharsimi A. (2011). Prosedur Penelitian.Jakarta: Bumi Aksara.

— (2009). Dasar-dasar EvaluasiPendidikan. Jakarta:Bumi Aksara

Suharsimi. A, \& Cepi, S. (2009). Evaluasi Program Pendidikan. Jakarta: Bumi Aksara 